\title{
Land Drainage Development Processes and Changes in the Context of Runoff Change in Northern Lithuania
}

\author{
Rasa Stankevičiené, Oksana Survilè \\ Department of Environmental Protection and Water Engineering, \\ Vilnius Gediminas Technical University, Vilnius, Lithuania
}

Received 4 February 2020; accepted 31 March 2020

\begin{abstract}
The impact of the drainage of excessively wet land on river runoff has so far been assessed differently and very carefully because of its complexity and diversity. The article analyses changes of drained land areas and runoff in the river basins of Mūša, Lèvuo Tatula and Nemunèlis. Wet land areas in the Mūša, Lèvuo and Nemunèlis rivers basins account for more than $70 \%$ from the total basins area and in the Tatula about $90 \%$. Increase of drained land areas in the studied river basins has no significant influence on the change of river runoff. Studies have shown that the change in drained land areas did not affect the change in runoff height. Drainage does not have a significant effect on changes in the annual runoff distribution of the studied rivers.
\end{abstract}

Keywords: draining, land drainage, river runoff, wetland.

\section{Introduction}

From the beginning of agriculture, land drainage has become an integral part. There are now more than 180 land drained and over 290 million irrigated hectares. Climatic conditions and physical geographical factors make the territory of Lithuania 3.4 million ha of excessively moist land or about $86 \%$ of the total agricultural area which can only be used intensively and productively after draining. As the economic and political conditions changed, the scope of land reclamation work also changed. 1970 In Lithuania there were 1 million ha of land drained by drainage, $1978-$ already 2 million ha, and in 1990 - 2.6 million ha (Ruminaite \& Barvidienè, 2011). After the 1990 restoration of independence, when Lithuania had to move from planned to market economy, new drainage systems are hardly installed. The installation of new drainage systems has been greatly reduced due to persistent lack of funds. At present in Lithuania, new systems are almost non-existent and only minor repairs or renovations to old systems are carried out (Ruminaite, 2010). The impact of drainage is rather complex and multifaceted, as changes in runoff during drainage works in river basins do not occur immediately, but gradually and depend on many factors, especially climatic conditions (Holden et al., 2006).

Drainage works include river bed straightening, dredging, drainage system installation. How landscapes have changed as a result of drainage works can only be seen by looking at the various pre-existing maps and comparing them with current. They show that the hydrographic network has changed very rapidly, which has influenced the formation of runoff (Sofia et al., 2019; Cazorzi et al., 2013). Drainage works have partially or completely destroyed the natural river bed vegetation, water imbalance was formed and drainage systems helped the fertilizers to drain faster from the cultivated fields to the water bodies. On the other hand, drainage systems reduce the amount of water in the soil during the vegetation period, creating favorable conditions for the growth of crops (Krause et al., 2007).

\section{Research object and methodology}

Research are carried out in the river basins of Mūša, Nemunèlis, Lèvuo, Tatula, which cover most of northern Lithuania (Figure 1). In these river basins, too wet land accounts for 70-89\% of the catchment area. The characteristics of the river basins selected for analysis are presented in Table 1.

${ }^{*}$ Corresponding author. E-mail: rasa.stankeviciene@vgtu.lt 


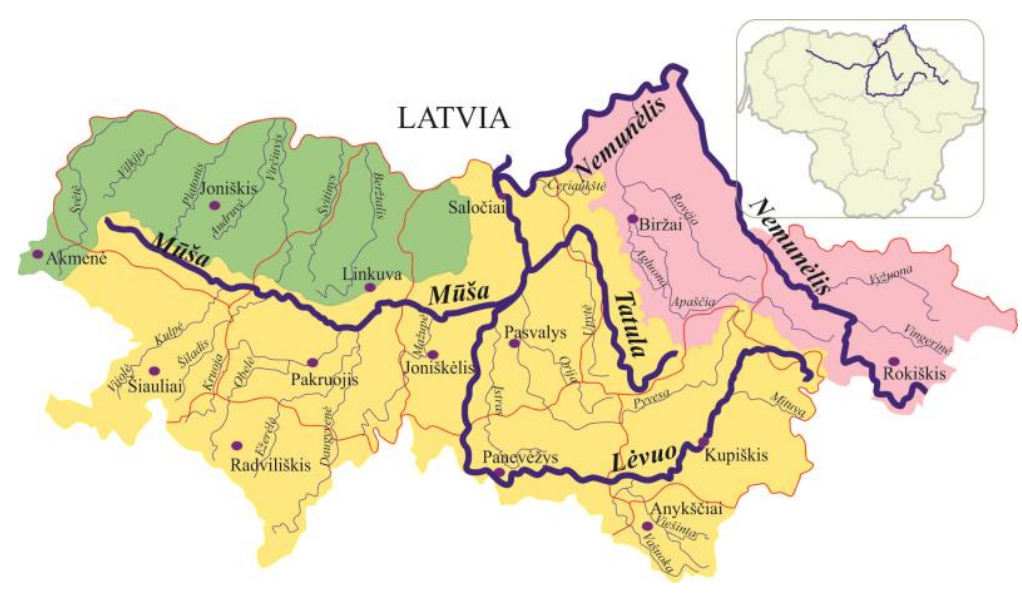

Figure 1. Research Mūša, Nemunèlis, Lèvuo, Tatula rivers

In these river basins, too wet land accounts for $70-89 \%$ of the catchment area. The characteristics of the river basins selected for analysis are presented in Table 1.

Table 1. Characteristics of the research rivers

\begin{tabular}{|c|c|c|c|c|}
\hline Rivers & $\begin{array}{c}\text { Basin area, } \\
\mathrm{km}^{2}\end{array}$ & $\begin{array}{c}\text { Wetland fund, \% of basin } \\
\text { area }\end{array}$ & $\begin{array}{c}\text { Lakes area in the rivers } \\
\text { basins, } \%\end{array}$ & $\begin{array}{c}\text { Forest area in the rivers } \\
\text { basins, } \%\end{array}$ \\
\hline Mūša & 2280 & 76 & 0.8 & 14 \\
\hline Lèvuo & 1560 & 72 & 0.4 & 15 \\
\hline Nemunèlis & 2690 & 73 & 0.6 & 24 \\
\hline Tatula & 404 & 89 & - & 8 \\
\hline
\end{tabular}

All the river basins studied have small lakes (only $0.4-0.8 \%$ ) and wetlands (3.0-10\%) areas, of which only a small part (about $3 \%$ of their total area) was drained. Thus, it is mainly the periodic wet mineral soils that are drained here. Wet land fund covering $70-90 \%$ of the basin area.

The alternation of the drained areas ( $\%$ of the territory of the basin and the wetland area) was established by using the data of the wetland cadastre. The data was collected according to the borders of the territories of the municipalities and later recalculated for the river basin district by establishing what part of the territory of the basin is covered by the wetland and drainage areas. In order to analyze the alternation of the river wateriness, the data of the long-termed water debit gauging accumulated in the Hydrometeorology Service of Lithuania (period of 1960-2017) was used. According to this data, the tendencies of the alternation in the river runoff while changing the drainage areas were analyzed. The runoff non-uniformity coefficient $d$ describes the annual distribution of runoff between the wet and dry seasons (Gailiušis \& Kovalenkovienè, 1998):

$$
d=\frac{\sum Q_{p}-Q t_{p}}{365(6) \cdot Q}
$$

here: $\Sigma Q_{p}$ - sum of daily flows for period $t_{p}$ where flows $Q_{p}$ are greater than average annual flow $Q$.

To evaluate the reliability of the results and to establish the statistical relationship between the variables, the methods of mathematic statistics are used and the main statistical parameters are calculated.

\section{Results}

Due to anthropogenic activity, changes in the water circulation between surface and subsurface aquifers are possible, and these changes can also be caused by global climate change - due to warmer winters and reduced water reserves in snow cover, decreased depth of frost, reduced frost duration and more frequent winter thaws. The development of the drainage areas of the Mūša, Lèvuo, Tatula and Nemunèlis River basins, their impact on the runoff of rivers during the period 1960-2017 were analyzed.

Changes in drained land areas. The northern part of Lithuania is one of the most important agricultural production regions in Lithuania. Therefore, in this region, land drainage is a very important tool for creating good conditions for intensive farming. Drainage improves soil physical properties - soil structure, filtration, temperature regime. Positive 
change in physical properties improves soil water regime, while improving drainage performance. Drainage drained lands also reduce surface runoff and increase underground, ground runoff. Such changes may influence the trends in the annual distribution of river runoff and the magnitude of runoff in different seasons. The wetlands cover more than $70 \%$ of the total area in the Mūša, Lèvuo and Nemunèlis rivers basins, and Tatula as much as $90 \%$. Analysis of changes in excessively wet lands and drained areas, during the period 1960-2017 in the river basins under study (Table 2) it was established that by 1961 drained land represented only 4-7\% of the basins area or 7-9\% of the wetland area.

Table 2. Variation of drained land areas ( $\mathrm{a}$ - drained land area in percent of total basin area, $\mathrm{b}$ - in percent of wetland area)

\begin{tabular}{|c|c|c|c|c|c|c|c|c|}
\hline \multirow{2}{*}{ Periods } & \multicolumn{9}{|c|}{ Rivers } \\
\cline { 2 - 9 } & \multicolumn{2}{|c|}{ Mūša } & \multicolumn{2}{c|}{ Lèvuo } & \multicolumn{2}{c|}{ Tatula } & \multicolumn{2}{c|}{ Nemunėlis } \\
\cline { 2 - 9 } & $a$ & $b$ & $a$ & $b$ & $a$ & $b$ & $a$ & $b$ \\
\hline Until 1961 & 7 & 7 & 7 & 9 & 4 & 7 & 5 & 8 \\
\hline $1961-1970$ & 37 & 48 & 36 & 49 & 47 & 53 & 34 & 48 \\
\hline $1970-1975$ & 48 & 61 & 43 & 59 & 60 & 67 & 47 & 62 \\
\hline $1975-1980$ & 58 & 75 & 52 & 71 & 72 & 80 & 56 & 73 \\
\hline $1980-1985$ & 63 & 81 & 57 & 76 & 78 & 84 & 59 & 78 \\
\hline $1985-1990$ & 66 & 86 & 58 & 80 & 81 & 88 & 62 & 81 \\
\hline $1990-1995$ & 69 & 87 & 60 & 81 & 81 & 89 & 79 & 82 \\
\hline $1995-2000$ & 68 & 89 & 59 & 82 & 80 & 91 & 80 & 83 \\
\hline $2000-2017$ & 68 & 89 & 59 & 82 & 80 & 91 & 80 & 83 \\
\hline
\end{tabular}

In the period between 1961 and 1970 the drained land area in the study basins was 34-47\% of the basin area or $48-53 \%$ of the wetland area. Over the next five years (1970-1975) the drained land area increased by $9-13 \%$ from the basin area, or 13-14\% from the wetland fund. During the period 1975-1980, the leap of drainage works was also recorded which increased the area of drained land to $52-72 \%$ of the catchment area or $71-80 \%$ of the wetland fund. 1980-1985 (compared to pre-1970), the area of drained land increased significantly, reaching $76 \%$ to $84 \%$ of wetland area. A decade later, between 1990 and 1995, drained land in the study basins accounted for $60-81 \%$ of the basin area, or $81-89 \%$ of the wetland fund. Since 2000 In the Mūša, Lèvuo and Nemunèlis River basins, the drained land already accounted for $82-89 \%$ and in the Tatula basin $91 \%$ of the wetland fund. In recent years, new drainage systems almost non-equipped, consequently, the areas of drained land changed little.

Change in river runoff. The annual distribution of runoff was estimated by calculating runoff non-uniformity coefficient $d$ values over different time periods, which differing in areas of drained land. It was found that in the period before 1970, when there was a small part of drained lands, the values of the runoff non-uniformity coefficient varied from 0.51 (in the Tatula and Lèvuo rivers) to 0.59 in the river Mūša. During the period (1980-1990), when the drained lands were already about twice as large, the runoff non-uniformity coefficients varied from 0.43 to 0.52 in the studied rivers - they decreased by 11-15\%. Comparing these changes with the values established over a multiannual period (Gailiušis et al., 2001), which varied from 0.46 to 0.56 for the rivers studied, the results show that no significant changes occurred. Leakage non-uniformity coefficients of this magnitude mean that: first, these rivers have the least leveled runoff per year, and second, that drainage has no major influence on the annual distribution of runoff in the rivers studied. The analysis of the runoff observations of the Mūša, Lèvuo, Tatula and Nemunėlis rivers shows that the cyclic fluctuations characteristic of the runoff change remain, when the phases of the aquatic cycle alternate the dry phases.

In the analysis of the impact of drainage on runoff, spring runoff values are particularly important. Land drainage systems play a key role in the spring, the snow melt period, because they allow faster removal of excess water from arable land, and this allows the start of spring field work about 2 weeks early and expect a more abundant harvest. It is also very important to remove as much water as possible in the fields during the summer season after heavy rainfall, because excess moisture in the soil can result in partial or complete loss of crop yields, impossible to harvest. During the spring (March, April) and summer (May, June, July, August) seasons, this excess water drains into rivers more quickly, however, excess water enters them during the same season and therefore cannot have a significant influence on the runoff of the rivers during these seasons.

The height of river runoff varied quite widely over the studied seasons (Figure 2). The highest values of runoff height are observed in years when rainfall is above normal. During spring season the runoff height in rivers studied ranged from 9 to $195 \mathrm{~mm}$ and in summer season from 6 to $137 \mathrm{~mm}$. The highest amplitudes of spring and summer runoff height variations were observed in the Tatula River during the whole study period. There were years when this river had a spring runoff height of $195 \mathrm{~mm}$ and a summer runoff height of $129 \mathrm{~mm}$. The greater variation in runoff height in this river may be due to the small area of the basin as small river basins are very sensitive to the effects of 
natural factors. The smallest amplitude of variation was observed in the Lèvuo River, where the height of spring runoff did not exceed 100 and in summer $48 \mathrm{~mm}$. The most common peak runoff height values were found between 1985 and 1990, when rainfall was $13 \%$ higher than the precipitation norm (605 mm). Minimum runoff height values were found between 1970 and 1975, when rainfall was $11 \%$ below precipitation norm.

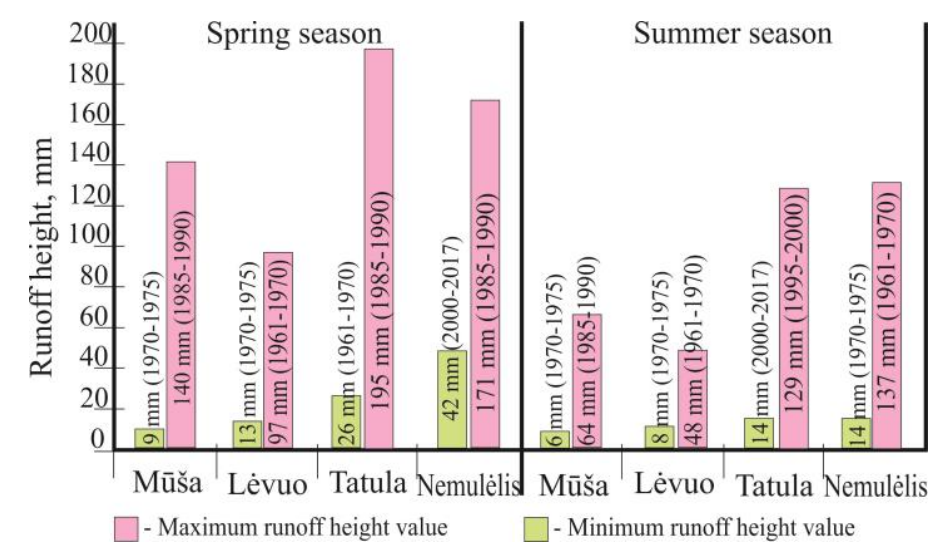

Figure 2. Changes in runoff height amplitudes during spring and summer seasons

Analyzing the changes of spring and summer runoff heights and drained land areas, the same regularities were found. In both spring and summer seasons (calculated on the basis of the proportion of wetland area in the whole river basin, and by the proportion of drained lands from the wet lands fund in the river basin) the correlation between runoff height and drained land areas changes across all the rivers studied is very weak or no correlation exists. Correlation coefficients vary from 0.17 to 0.22 in spring and from 0.04 to 0.44 in summer seasons ( $95 \%$ confidence level $p<0.05$ ).

Studies have shown that the change in drained land areas did not affect the change in runoff height (both during spring floods and summer floods).

\section{Conclusions}

Wet land areas in the Mūša, Lèvuo and Nemunèlis river basins account for more than $70 \%$ from the total basins area, and in the Tatula about $90 \%$.

By 1961, it was found that in the study area the drained land area was 7-9\% of the wetland area. Since 2000 in the Mūša, Lèvuo and Nemunèlis river basins, the drained land already accounted for $82-89 \%$ and in the Tatula basin $91 \%$ of the wetland area.

At the beginning of the study period (until 1961) in the Mūša, Lèvuo, Tatula and Nemunèlis river basins, the total drained land area was 4-7\% of the basins area, and by the end of the period under investigation they had reached 59$80 \%$. In recent years, new drainage systems almost non-equipped, consequently, the areas of drained land changed little.

The annual distribution of runoff was estimated by calculating runoff non-uniformity coefficient $d$ values during different periods which differ in the area of drained land. Comparing the results obtained with the values established over a multiannual period, we conclude that no substantial changes have occurred. Drainage does not have a significant effect on changes in the annual runoff distribution of the studied rivers.

Increase of drained land areas in the studied river basins has no significant influence on the change of river runoff. The correlation between the spring and summer runoff height and the area drained by drainage is very weak or weak. In the spring season, the correlation coefficients vary from - 0.17 to 0.22 , and in the summer - from 0.04 to 0.44 .

\section{References}

Cazorzi, F., Fontana, G. D., De Luca, A., Sofia, G., \& Tarolli, P. (2013). Drainage network detection and assessment of network storage capacity in agrarian landscape. Hydrological Processes, 2(15), 541-553. https://doi.org/10.1002/hyp.9224

Gailiušis, B., \& Kovalenkovienè, M. (1998). Lietuvos upių nuotėkio netolygumas. Aplinkos tyrimai, inžinerija ir vadyba, 2(7), 3-9.

Gailiušis, B., Jablonskis, J., \& Kovalenkovienė, M. (2001). Lietuvos upés. Hidrografija ir nuotèkis (790 p.). Lietuvos energetikos institutas.

Holden, J., Chapman, P. J., Lane, S. N., \& Brookes, C. (2006). Chapter 22 Impacts of artificial drainage of peatlands on runoff production and water quality. Developments in Earth Surface Processes, 9, 501-528. https://doi.org/10.1016/S0928-2025(06)09022-5 
R. Stankevičiene, O. Survile. Land drainage development processes and changes in the context of runoff change...

Krause, S., Jacobs, J., \& Bronstert, A. (2007). Modelling the impacts of land-use and drainage density on the water balance of a lowland-floodplain landscape in northeast Germany. Ecological Modelling, 200(3-4), 475-492.

https://doi.org/10.1016/j.ecolmodel.2006.08.015

Ruminaitè, R. (2010). Antropogeninès veiklos ịtakos upiu nuotékiui ir vandens kokybei tyrimai ir vertinimas (Doctoral dissertation). Vilnius Gediminas Technical University, Vilnius, Lithuania.

Ruminaite, R., \& Barvidienè, O. (2011, May 19-20). Impact of land drainage and natural factors on the changes of the hydrological regime of the Tatula river. 8th International Conference "Environmental Engineering", selected papers, Water Engineering. Energy for Building, 2, 654-658. Technika. ISSN 2029-7106.

Sofia, G., Ragazzi, F., Giandon, P., Fontana, G. D., \& Tarolli, P. (2019). On the linkage between runoff generation, land drainage, soil properties, and temporal patterns of precipitation in agricultural floodplains. Advances in Water Resources, 124, 120 138. https://doi.org/10.1016/j.advwatres.2018.12.003 